\title{
Modern Model of a Rural Settlement: Development of Planning Structure and Reconstruction of Villages
}

\author{
Alla Aleksandrovna Kornilova, Yevgeniya Mikhaylovna Khorovetskaya, Tatyana Alekseevna \\ Abdrashitova*, Ainur Barlybayevna Smagulova, Irina Vladimirovna Lapteva \\ Department of Architecture and Design, Faculty of Land Management, Architecture and Design, S.Seifullin Kazakh Agro Technical \\ University, Kazakhstan
}

Received August 24, 2020; Revised December 15, 2020; Accepted January 20, 2021

\section{Cite This Paper in the following Citation Styles}

(a): [1] Alla Aleksandrovna Kornilova, Yevgeniya Mikhaylovna Khorovetskaya, Tatyana Alekseevna Abdrashitova, Ainur Barlybayevna Smagulova, Irina Vladimirovna Lapteva, "Modern Model of a Rural Settlement: Development of Planning Structure and Reconstruction of Villages," Civil Engineering and Architecture, Vol. 9, No. 1, pp. 214 - 224, 2021. DOI: 10.13189/cea.2021.090118.

(b): Alla Aleksandrovna Kornilova, Yevgeniya Mikhaylovna Khorovetskaya, Tatyana Alekseevna Abdrashitova, Ainur Barlybayevna Smagulova, Irina Vladimirovna Lapteva (2021). Modern Model of a Rural Settlement: Development of Planning Structure and Reconstruction of Villages. Civil Engineering and Architecture, 9(1), 214 - 224. DOI: 10.13189/cea.2021.090118.

Copyright@2021 by authors, all rights reserved. Authors agree that this article remains permanently open access under the terms of the Creative Commons Attribution License 4.0 International License

\begin{abstract}
The study is aimed at developing a modern model of a rural settlement that corresponds to the socioeconomic conditions of the market economy in Kazakhstan and modern ideas about architectural planning solutions of an aesthetic nature. The proposed model will help researchers, experts, specialists in preparing recommendations for the development of rural settlements of various levels, depending on the administrative and economic significance, population size, national, regional characteristics. Villages at the present stage of development of Kazakhstan vary significantly both in importance (farm center, rural districts, etc.) and in population size (from 5,000 to 50 people), as well as in the status of territorial zones (residential and industrial zones).The study has allowed to:- reveal the dynamics of the development of rural settlements, their architectural and planning structure in time and space;- determine the dominant factor and priority approach to the formation of the architectural and planning structure of the village at each historical stage;- identify the reasons for the degradation of the architectural and planning structure of villages in the historical context;- define that the architectural and planning structure with the traditionally clear functional zoning of villages has been gradually replaced by diffuse-penetrating structure;- reveal that the mutual position of the main functional zones has changed, the production zone and the community center have
\end{abstract}

undergone the greatest transformation;- develop a theoretical model of the formation of the architectural and planning structure of rural settlements; identify the main aspects and principles of its formation.

Keywords Structure, Architecture, Principles, Economics, Regional Specifics, Composition, Territory

\section{Introduction}

Significant changes have taken place in the Republic of Kazakhstan since it became independent. At first glance, it may seem that political, social, and economic changes are not related to the planning, development, and improvement of the aul (village). However, it is actually much more complicated. For example, the villagers often placed the economic center on their own personal plot when creating their farms. This led to a multiple increase in the livestock population in the residential area, influenced the environment of the village, and disrupted the architectural and planning structure.

In turn, the architectural and planning structure influences the level of public services and amenities, migration, and the comfort of the villagers' life. Accordingly, in the conditions of market relations and 
rationalization of the space development on the territory of the Republic, the need for the development of programs, forecasts, schemes, and projects for the territorial development of settlement and rural areas is currently increasing as a means of comprehensive solving acute socioeconomic and environmental problems.

In the modern conditions of the development of agriculture in the Republic of Kazakhstan and the economy as a whole, it has become necessary to revise the existing settlement system. The issues on the agenda include the contradictions between society and nature, social demands, and the requirements for the location of production, between the location of production and environmental protection. The settlement of the population on the territory is currently a state problem due to the development of productive forces, social needs of society, and environmental protection.

At the same time, it must be noted that the creation of food supply in the country is impossible without agriculture, which is directly or indirectly related to the living conditions of the villagers and the spatial formation of settlements.

There are studies that consider the role of small settlements in the general settlement system, using examples from different countries of the world, as well as the principles of forming their planning structure, depending on regional conditions.

For example, the issues of planning cities and rural areas, as well as the settlement issues were considered by M.A. Gendelman, V.G. Davidovich, V.A. Lavrov, V.M. Bogdanov, I.A. Vinshu, Le Corbusier [1], A.N. Kondukhov, I.M. Smolyar, T.K. Basenov [2], N.F. Golikov, U.M. Iskakov, D.K. Chudinov, Z.N. Yargina, O.K. Gurulev [3], A.V. Ikonnikov [4], V.N. Belousov [5], V.P. Baskakova, A.E. Likhacheva [6], V.I. Krushlinsky, Z.N. Yargina [7], A.Zh. Abilov [8], as well as modern authors [9].

Yu.L. Pivovarov, S.G. Khorev, P. Marlene, B.I. Ogly, I.G. Lezhava, A. Baburov [10], and others dealt with the problems of urbanization.

The architectural, artistic, and compositional aspects of the formation of populated areas were explored in the works of Ya.V. Kositsky, M.G. Barkhin, A.V. Bunin, N.V. Novikov, A.N. Beregovskikh [11], and others.

National, social, and economic transformations in the settlements of Kazakhstan are presented in the works of G.F. Dakhshlaiger, N.V. Alekseenko, A.E. Some, D. Kabylbekov, G.I. Pustovetov [12], V.V. Musatov, Kh.A. Butusov, V.A. Novikov [13], S.B. Pomorov [14], A.A. Kornilova, and others [15, 16].

Part of the modern works explore the historical evolvement of urban development activities in the region, which is confirmed in the articles "Urban Planning and Recreational Planning of Populated Areas in the Republic of Kazakhstan in the Second Half of the 20th Century" [15] and "Historical aspects of the formation of rural settlements in northern Kazakhstan during the pre-revolutionary period” [16].

It must be noted that extensive empirical material has been accumulated on the topic under study during the functioning of the market economy, but it has not found the proper creative generalization and, therefore, no proposals (principles) for a new approach to the architectural and planning solution of villages and their reconstruction in the market economy have been developed.

The study is aimed at developing a theoretical model of the formation of rural settlements.

Accordingly, the aim of the study is driven by its relevance. In its turn, the relevance of the study is associated with the following:

- a radical change of ownership in villages, privatization of agricultural enterprises, and creation of a new system of farms;

- migration of large masses of the population and a decrease in the population in some villages and auls;

- changes in the situation in the development and formation of the architectural and planning structure of rural settlements, which is associated with the abandonment and destruction of some public institutions, industrial buildings, and engineering structures;

- a significant increase in the role of private subsidiary farming, its development, and growth in size;

- creation of a farming network, including farm centers; - complex environmental situation; and

- lack of scientific developments and scientifically grounded recommendations for the development of villages and the formation of their architectural and planning structure in the new socioeconomic conditions of Kazakhstan.

The idea of the article is associated to the resumption of resettlement and reconstruction of villages at the present stage, which raises the urgent question of their appropriate classification in relation to specific conditions.

In this regard, it is necessary to foresee how villages should develop today in the future in order to use capital investments in agriculture with the greatest efficiency, carefully substantiate planning solutions with consideration of the development of settlements, national traditions, and local characteristics, as well as the rational use of territories, landscape, climate, and natural resources.

This work is based on many years of research, analysis of the historical and modern conditions for the formation of villages and the study of social and regional aspects, which allows laying the scientific foundations for the reconstruction and improvement of agricultural settlements, taking their regional characteristics into account.

The leading hypothesis is that the optimal state of the formation of rural settlements is achieved with comprehensive consideration of all factors and elements, taking the vector of time dynamics into account. 


\section{Materials and Methods}

Following the hypothesis, various research methods were used in the work, based on a comprehensive and detailed consideration of the solution to the problem posed, the study of objects and their specifics in a variety of interrelationships and relative independence.

The forecast for the development of rural settlements was determined based on the method of expert assessments.

As part of the expert assessments (current state, trends, and prospects), an interview was conducted with the experts (253 people), who were offered a questionnaire of 12 questions covering the main functions of agricultural production and living conditions of people. The experts were highly qualified specialists of various professions and ranks. The goal of the study was to obtain a forecast of the development of rural settlements from a competent group of workers.

The methods of applied sociology were used in surveys of the rural population, heads of collective farms, LLCs, JSCs, rural districts, district akimat, chief specialists, mid-level specialists, school teachers, and cultural workers. These methods were applied to determine the prospects for further development and use of rural areas. The interlocutors for the interview were chosen according to the principles of education, which provided the necessary level of judgment.

The polling was carried out in three stages:

Stage I in 2005 - 2009;

Stage II in 2010 -2014 ; and

Stage III in 2015 - 2019.

The face-to-face method of polling was used, with filling out questionnaires at home (in case of an individual interview) and on the spot in a group interview, with handouts provided.

The authors developed tools (which were corrected and modified at each stage), presented as follows:

\section{Questionnaire:}

- to poll the rural population;

- to interview the heads of farms; and

- to interview the experts.

2. Points:

- points for the village;

- demographic points;

- points describing production and settlement; and

- points describing farms over five years.

In the course of the polling, the typical method of organizing the sample was determined, and the size of the sample was defined using the formula.

More than a thousand families with a total population of 4,488 people were interviewed at Stage I. The survey was conducted in 37 settlements.

The same number of settlements was taken at Stages II and III, for comparison with Stage I.

The survey allowed to determine the main structure forming elements of the formation of rural settlements with the help of a public visual image (social image) based on the conventional ideas about the subject.

The mathematical statistical techniques were used to process the massive statistical material - in particular, to process questionnaires of the population poll and other data on the aggregate of rural settlements, etc. The methods of groupings and correlation regression analysis were used to identify links between the size of rural settlements and their architectural and planning solutions by the example of the Akmola region. The sampling method was applied in this situation. The methods of extrapolation, expert assessment, and verification of forecasts were used to determine the prospects for the development of rural settlements, production volumes, location of economic centers, size of private subsidiary farming, etc.

The final forecast for the formation of villages was made on the basis of a logical summation of the data obtained by different methods.

All analytical conclusions were based on the following:

- expeditionary research in the region under study (2005 - 2019) in order to conduct field surveys of settlements aimed at identifying the peculiarities of the formation of the planning structure of settlements (a number of settlements were selected for research, typical for natural, economic, historical, national, and demographic conditions); 299 rural settlements, 27 regional centers, and 12 cities were surveyed (the sample was substantiated by the recommendations of the University of Tartu; the data were representative); collection of the state statistics (list of settlements and their importance in the settlement system, information on population migration, placement of cultural and household facilities, and the state of the housing stock);

- study of geographical atlases, climate reference books, and statistical and environmental reports;

- study of the expert opinions;

- study of the planning structure and improvement of villages, using photographic plans and general plans of villages; and

- collection of archival and historical materials.

\section{Results}

It was found in the course of the study that the main prerequisites for the reconstruction of rural areas at the considered stage were the following: the direction of the financial and economic policy of the state; determination of territories that were promising from the standpoint of the economy and market functioning; formation of a promising settlement system; and introduction of science 
and technology.

It was revealed in the survey of the rural population that migration was caused by negative consequences of sanitary and economic processes: poor living conditions (especially in small settlements), level of service, the desire to move to their historical homeland, decline in the education system, healthcare, culture, disorganization of life, lack of recreation areas, as well as climatic and landscape conditions. That was noted by $93 \%$ of the respondents (Table 1).

It is important to note that similar reasons for migration were observed in agricultural settlements in other countries [17]. Migration trends in the region can be traced based on the following schemes (Figures 1, 2).

Table 1. Factors affecting population migration (based on the results of the survey)

\begin{tabular}{|c|c|c|c|}
\hline Factors & Istage & IIstage & IIIstage \\
\hline Poor livingconditions & $20.5 \%$ & $23.5 \%$ & $19 \%$ \\
\hline Low level of cultural and consumer services & $20 \%$ & $17.3 \%$ & $16.6 \%$ \\
\hline Lack of recreation areas & $2.1 \%$ & $0.8 \%$ & $7 \%$ \\
\hline Decline in the culture and education system & $14 \%$ & $20 \%$ & $15.9 \%$ \\
\hline Decline in the healthcare system & $21.2 \%$ & $19.7 \%$ & $19 \%$ \\
\hline Unfavorableclimaticandlandscapeconditions & $6.2 \%$ & $4.3 \%$ & $9.1 \%$ \\
\hline Low level of public services and amenities & $4.7 \%$ & $0.9 \%$ & $2.5 \%$ \\
\hline Desire to move to the historical homeland & $9.3 \%$ & $13 \%$ & $10 \%$ \\
\hline Unsatisfactory transport links with adjacent settlements & $2 \%$ & $0.5 \%$ & $0.9 \%$ \\
\hline Total & $100 \%$ & $100 \%$ & $100 \%$ \\
\hline
\end{tabular}

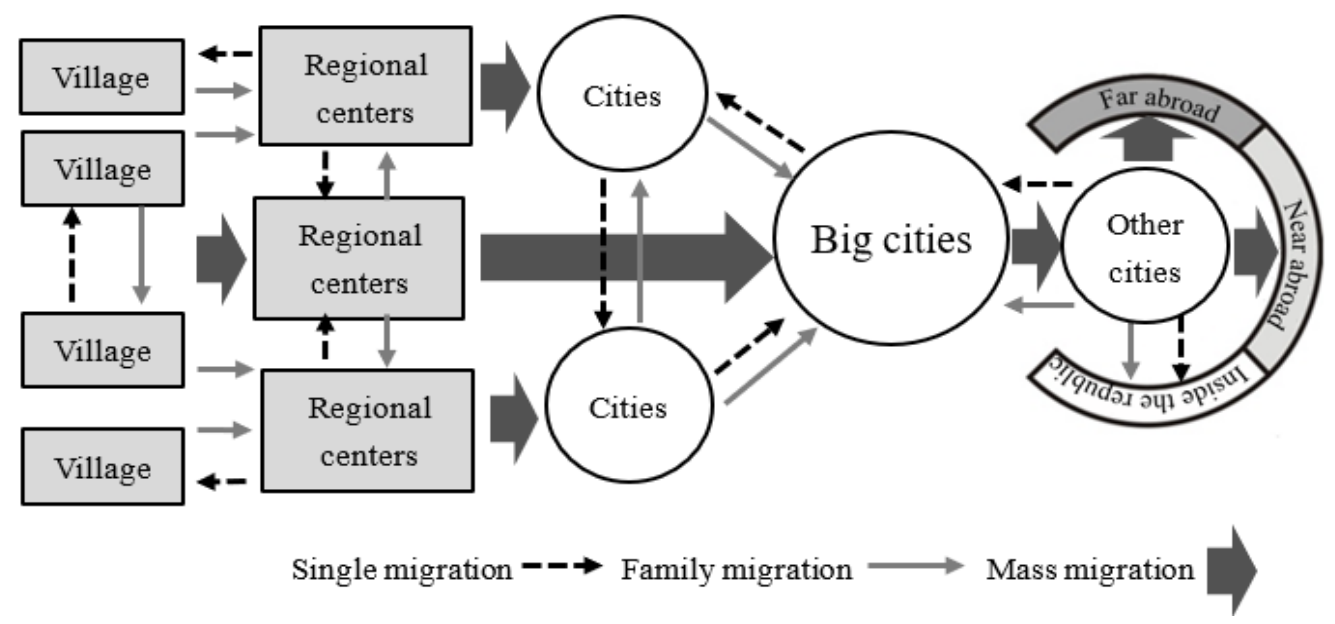

Figure 1. General structure of migration

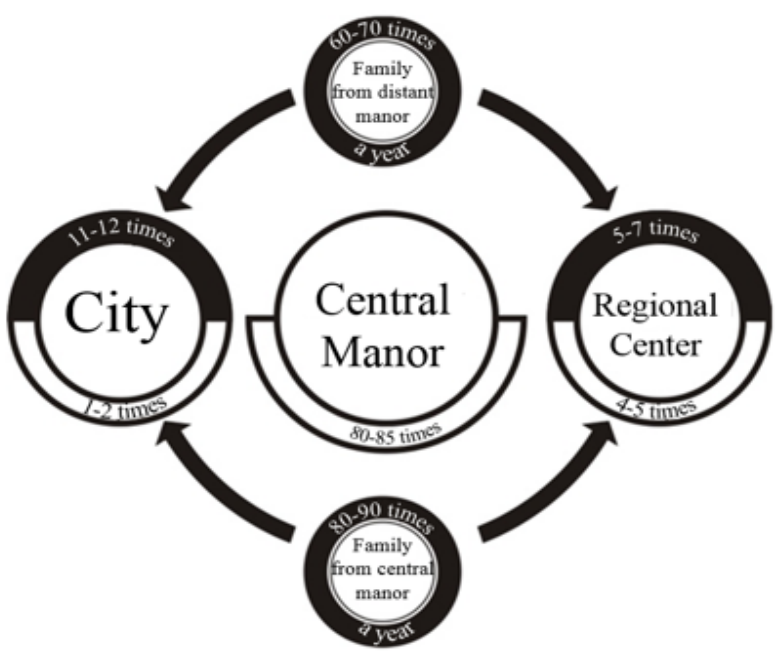

Migration Destination

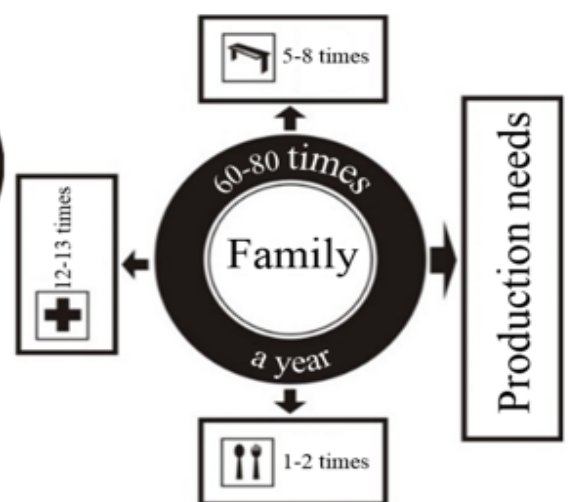

Migration Goal

Figure 2. Population migration throughout the year (pendulum migration) 
Accordingly, both general principles and specific ones must be taken into account when reconstructing the planning structure of villages. The general principles include relations between people, everyday life, and national characteristics. The specific principles include the settlement location, natural and climatic specifics, and the history of development. It was established that the following requirements were to be accounted along with the principles: social, aesthetic, organizational and economic, functional, economic and environmental.

As a result, it is proposed to consider the following issues when solving social problems:

- the new status of the owner and their family in the totality of industrial relations, position in the hierarchy;

- attitude to the development of private subsidiary plots, work in the cooperative, LLC, JSC, the creation of collective farms; and

- satisfaction with the established social infrastructure.

In regard to the economic problem:

- disclosure of the problems of reconstruction of villages in the conditions of market relations and private ownership of land;

- efficiency of the development of collective farms and private subsidiary farming;

- feasibility of creating a family livestock farm within the village;

- conditions for significant expansion of private subsidiary farming;

- possibility and profitability of acquiring land from neighboring private subsidiary farming; and

- expediency of land reclamation and increasing the area of private subsidiary farming.

The environmental problems are related to the pollution of the village, the placement of manure, feed, fuels, and lubricants on its territory.

The planning problems are divided into the following groups: impact of historical, climatic, socioeconomic factors, and administrative territorial transformations on the formation of rural settlement systems and the architectural and planning structure of rural settlements;

- analysis and identification of the specific architectural and planning structure of historically established types of villages, as well as the modern trends in the design of settlements;

- general architectural and planning composition, layout scheme, and functional zoning of the territory; fundamental solution to the problem of locating economic centers of agricultural formations on the territory of the village;

- identification of opportunities and analysis of options for the development and placement of private subsidiary farming and minifarms;

- study of options for the architectural and planning placement of settlements in relation to the differentiation of the size and location of private subsidiary farming and minifarms;

- designing the development and placement of material elements of the production area;

- analysis of options for placing a network of streets and cattle passes, economic driveways, organization of communication between farms and pastures;

- change in the classification of rural settlements is envisaged by administrative significance, by role in the system of cultural and consumer services, by functional purpose, and by geographical (territorial) location; and

- determination of the principles of formation and the main components of the conceptual model.

In accordance with the main planning tasks, a scheme of the functional and planning structure of rural settlements in the Republic of Kazakhstan was developed (Figure 3). 


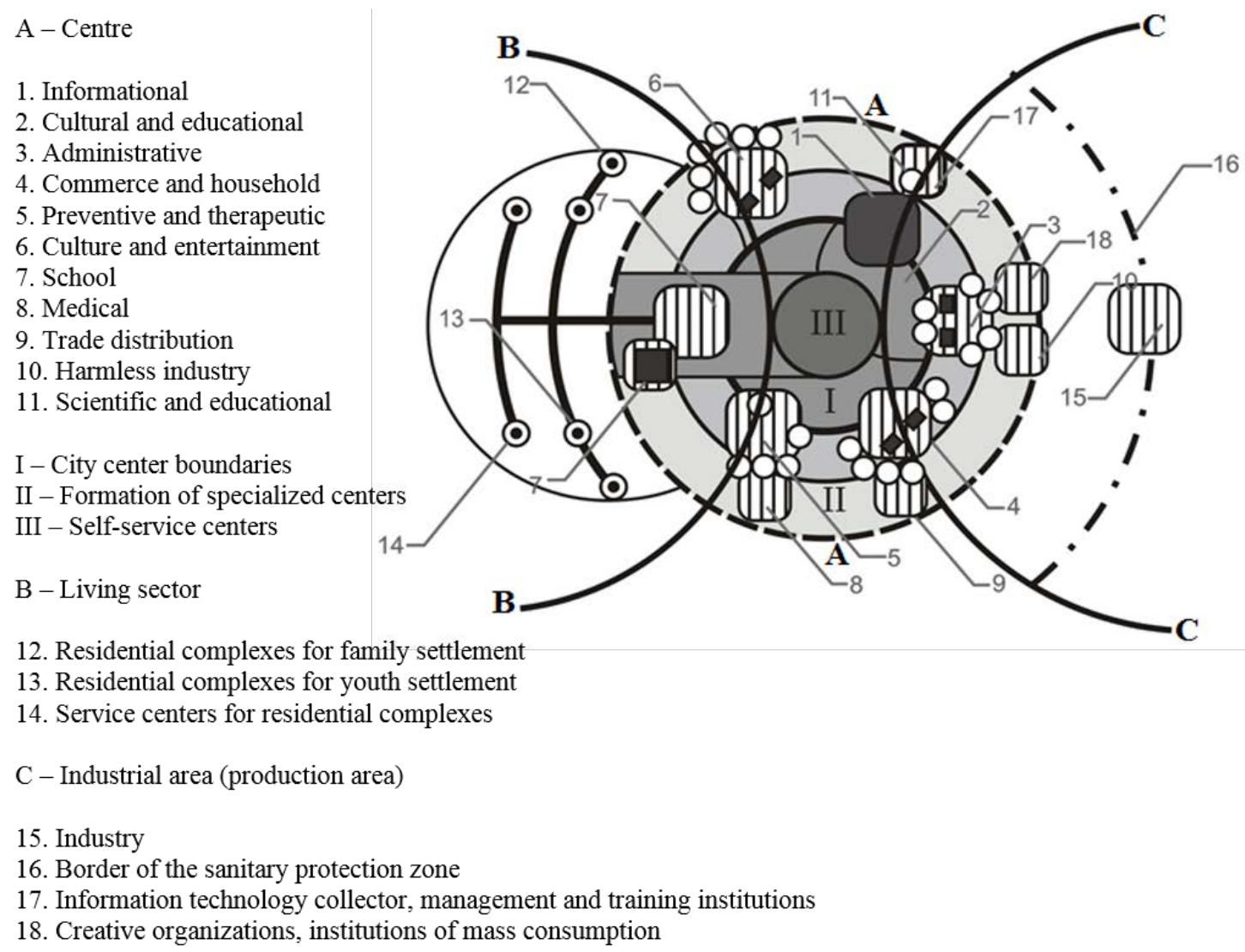

Figure 3. Schematic diagram of the functional and planning structure of rural settlements in the Republic of Kazakhstan

Different opinions on the issues of reorganization of rural settlements at the present stage must be noted. However, their reconstruction remains to be the main focus $[16,18]$.

It was revealed that the measures for the reconstruction of small settlements consisted in the transition from the predominant focus on the reconstruction of relatively autonomous settlements to the organization of settlement systems of various types and levels in the modern conditions. In this regard, the following is proposed:

- differentiation of rural areas by the degree of development of integration processes between the cities and villages;

- priority development of settlement systems in the territories allocated by location, as well as in the most developed zones in terms of using the resource potential;

- development of a set of measures to organize the economic integrity of settlement systems, taking specific conditions (economic, demographic, sociocultural, natural, and environmental) into account; and

- reconstruction of small settlements that develop relatively autonomously, taking into account the possibilities of strengthening their interconnection with the nearest urban centers.

It was revealed during the individual interviews with the chief specialists, middle-level specialists, school teachers, and cultural workers (face-to-face polling was used, with filling out questionnaires) that the following topical issues influenced the convenience, attractiveness, and appearance of settlements (where the indicators at all three stages differed only in tenths):

- principle of historical continuity (noted by $23.4 \%$ of the respondents);

- principle of synthesis of architecture and nature (35.4\%); and

- $\quad$ principle of reducing climatic discomfort (41.2\%) (Table 2). 
Table 2. Factors affecting the formation of the architectural and planning structure of small settlements and the comfort of living (based on the results of the survey)

\begin{tabular}{|c|c|c|c|c|c|c|c|}
\hline Group & Factors & $\begin{array}{c}\text { Chief } \\
\text { specialists }\end{array}$ & $\begin{array}{l}\text { Mid-levelspe } \\
\text { cialists }\end{array}$ & $\begin{array}{c}\text { School } \\
\text { teachers }\end{array}$ & $\begin{array}{l}\text { Cultural } \\
\text { workers }\end{array}$ & Average rate & $\begin{array}{l}\text { \% by } \\
\text { group }\end{array}$ \\
\hline \multirow{5}{*}{$\begin{array}{l}\text { The principle } \\
\text { of historical } \\
\text { continuity }\end{array}$} & $\begin{array}{l}\text { Taking into account the } \\
\text { historically established } \\
\text { planning structure }\end{array}$ & $7 \%$ & $7.3 \%$ & $6.8 \%$ & $6.9 \%$ & $7 \%$ & \multirow{5}{*}{$23.4 \%$} \\
\hline & $\begin{array}{c}\text { The } \\
\text { useoflocalbuildingmaterialsfor } \\
\text { villagereconstruction }\end{array}$ & $4.7 \%$ & $4.3 \%$ & $5 \%$ & $4.8 \%$ & $4.7 \%$ & \\
\hline & $\begin{array}{l}\text { The use of national colors in } \\
\text { the architecture of the village }\end{array}$ & $3.5 \%$ & $3.3 \%$ & $3.2 \%$ & $4 \%$ & $3.5 \%$ & \\
\hline & $\begin{array}{c}\text { The use of light and color in } \\
\text { village architecture }\end{array}$ & $4 \%$ & $4 \%$ & $3.9 \%$ & $4.5 \%$ & $4.1 \%$ & \\
\hline & $\begin{array}{c}\text { Taking into account } \\
\text { socio-economic conditions }\end{array}$ & $4.1 \%$ & $4.1 \%$ & $4.2 \%$ & $4 \%$ & $4.1 \%$ & \\
\hline \multirow{5}{*}{$\begin{array}{l}\text { The principle } \\
\text { of synthesis of } \\
\text { architecture } \\
\text { and nature }\end{array}$} & $\begin{array}{l}\text { Connection of the architectural } \\
\text { and planning solution with the } \\
\text { surrounding landscape }\end{array}$ & $9.5 \%$ & $9.3 \%$ & $8.7 \%$ & $8.9 \%$ & $9.1 \%$ & \multirow{5}{*}{$35.4 \%$} \\
\hline & $\begin{array}{l}\text { Reflection of the rural lifestyle } \\
\text { in the architecture and planning } \\
\text { of villages }\end{array}$ & $7 \%$ & $7.2 \%$ & $6.7 \%$ & $6.3 \%$ & $6.8 \%$ & \\
\hline & $\begin{array}{c}\text { The } \\
\text { useinthedesignoftheplanningstr } \\
\text { ucture: regular, free, mixed }\end{array}$ & $6.2 \%$ & $6.1 \%$ & $5.7 \%$ & $6 \%$ & $6 \%$ & \\
\hline & Organizationoftheyardspace & $7.9 \%$ & $7.7 \%$ & $6.9 \%$ & $7.1 \%$ & $7.4 \%$ & \\
\hline & $\begin{array}{c}\text { Organization of recreation } \\
\text { areas for year-round use }\end{array}$ & $6 \%$ & $6.4 \%$ & $6.1 \%$ & $5.9 \%$ & $6.1 \%$ & \\
\hline \multirow{5}{*}{$\begin{array}{l}\text { The principle } \\
\text { of reducing } \\
\text { climatic } \\
\text { discomfort }\end{array}$} & $\begin{array}{l}\text { Improvement of environmental } \\
\text { conditions }\end{array}$ & $5.5 \%$ & $5.5 \%$ & $5.7 \%$ & $5.3 \%$ & $5.5 \%$ & \multirow{5}{*}{$41.2 \%$} \\
\hline & $\begin{array}{l}\text { Functional organization of the } \\
\text { settlement territory }\end{array}$ & $10.9 \%$ & $10.7 \%$ & $10.3 \%$ & $10.5 \%$ & $10.6 \%$ & \\
\hline & $\begin{array}{c}\text { Reduction of natural and } \\
\text { climatic discomfort }\end{array}$ & $11.3 \%$ & $11.1 \%$ & $11.8 \%$ & $10.6 \%$ & $11.2 \%$ & \\
\hline & Landscaping of the settlement & $8.6 \%$ & $8.8 \%$ & $8.7 \%$ & $8.3 \%$ & $8.6 \%$ & \\
\hline & $\begin{array}{c}\text { Constructionzoningofasettleme } \\
n t\end{array}$ & $5.7 \%$ & $6 \%$ & $5 \%$ & $4.5 \%$ & $5.3 \%$ & \\
\hline
\end{tabular}

At the same time, the problem of continuity primarily influences the planning solutions using local regional specifics (historical, national, and socioeconomic) and is reflected in the formation of small settlements in terms of population and territorial size; functional organization of the territory; historically justified techniques (for the region under study) of the planning structure; rural image and identity during development; using traditional building materials, structures, volumetric spatial forms, and decor.

The study of the promising problems of urban development using the entire set of social forecasting tools is fundamental in the formation of an architectural model of the development of villages and their structural elements in this work.
The development of a theoretical model as the primary stage of urban planning means increasing the degree of scientific validity of urban planning schemes, programs, and projects.

The following tasks were set and solved when forming a theoretical model of agricultural settlements:

- improving environmental conditions;

- increasing the economic efficiency of agricultural production;

- intensification of integration ties; and intensification of land use.

The following factors were taken into account: natural, historical, national, resource, external, architectural and artistic, scientific, and technical (Figure 4). 
PRODUCTION
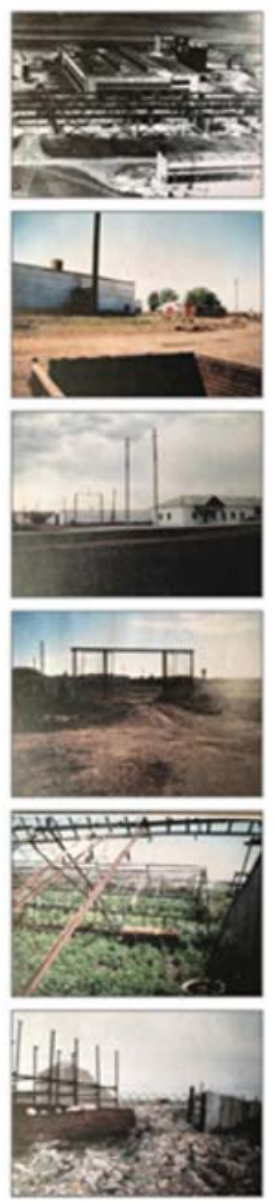

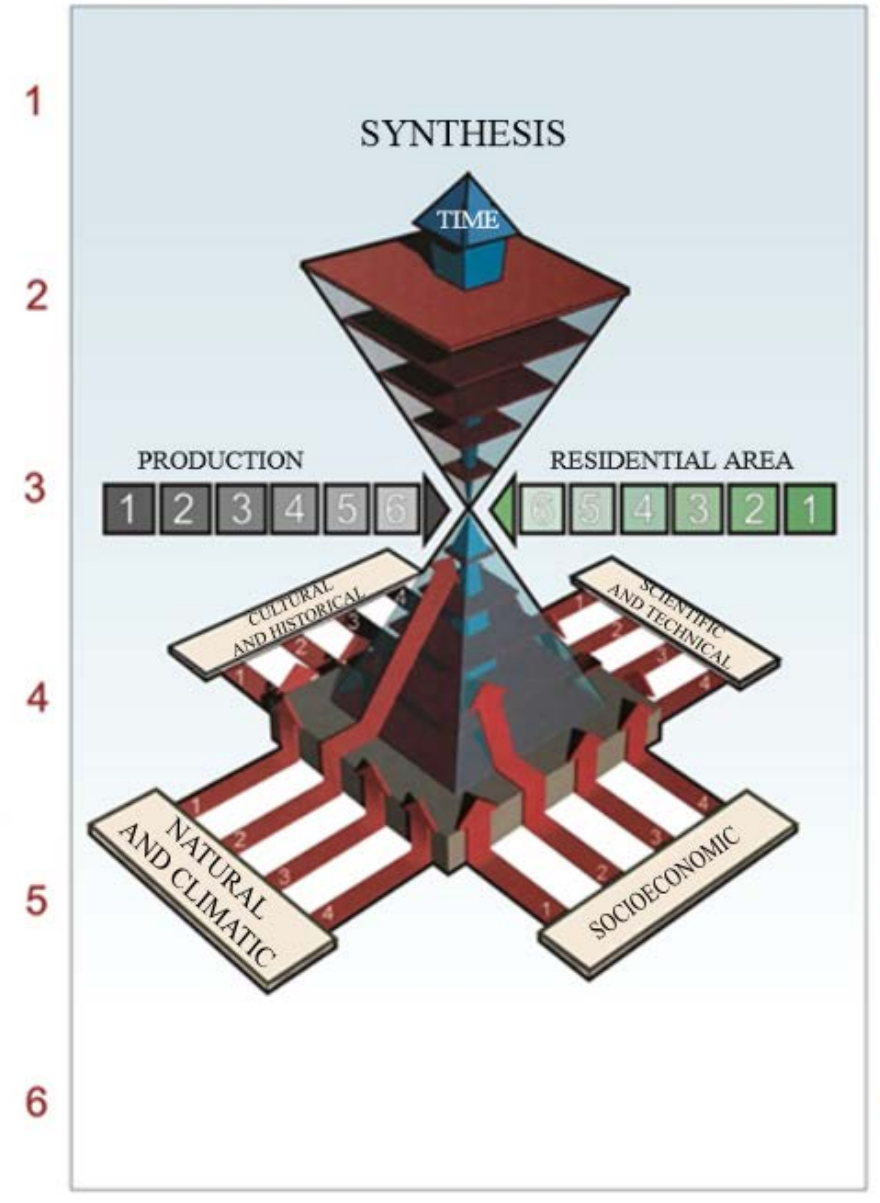

RESIDENTIAL AREA

1

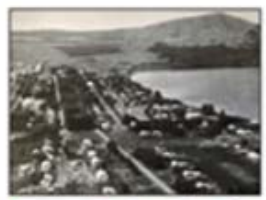

2

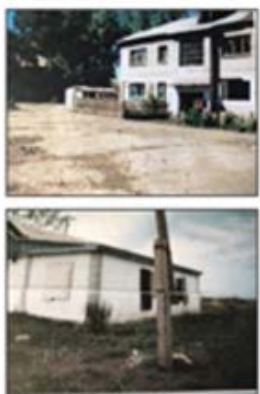

4

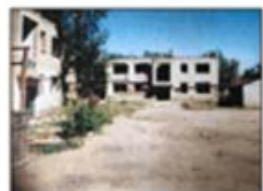

5

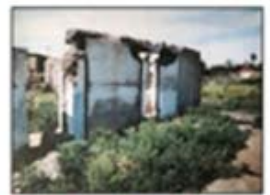

6

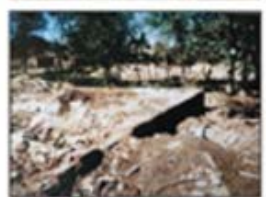

Figure 4. Theoretical model of transformation of the village planning structure

Taking into account the above factors will allow the following:

- natural factors will allow to ensure the comfort of the population in a particular settlement;

- historical factors will allow to provide for the placement of settlements in the historically justified zones, taking the traditional mode of production into account;

- resource factors will allow the rational use of land; and

- external factors will allow the settlement of the population (placement of settlements) in the spaces of economic interaction.

\section{Discussion}

The proposed theoretical model of the formation of an agricultural settlement is based on the main modern trends in the village development, which can be formulated as follows:

1. trends related to population demography and lifestyle;

2. trends related to urbanization, integration, and settlement structure;
3. trends related to the quality of the environment;

4. trends in the development of transport and communications;

5. trends arising from the limited natural and labor resources; and

6. trends in the housing design.

The theoretical model of the rural settlement formation is supposed to be introduced into production. The model provides for a stage-by-stage development of space: from the region as a whole to the placement of the elements of the village planning structure:

- the socioeconomic conditions, historical continuity, territorial differentiation, and natural landscape zoning are determined at the first stage;

- the structural spatial organization of the region with the allocation of the regional, zonal, and planning level (multilevel organization of space) is envisaged at the second stage;

- the search for the optimal solution within the allocated zone is performed at the third stage;

- the fourth stage includes the architectural and artistic organization of the space of a particular settlement at the planning level; and 
- the structural integration is arranged on the fifth level.

A multilevel system of organizing space involves the following:

- resolving the problem on the territory of Northern Kazakhstan: a regional territorial complex, taking specific conditions and requirements into account at the first level (regional level);

- the regional territorial complex is subdivided into zones at the second level (zonal level); and

- formation of a specific object (planning level) with the simultaneous placement of a public center, recreation area, housing, and transport are provided at the third level.

Residential formations within the settlement should be subdivided by the level of comfort, based on the cost characteristics of land and real estate. The following territories are distinguished within the settlement:

- territories of the first level provide increased comfort and are located in more favorable natural conditions;

- territories of the second level occupy the most preferred part of the settlement; and

- territories of the third level are of the general level and occupy the rest of the settlement.

In the theoretical model of the agricultural settlement formation, it is proposed to preserve and develop the existing trends in functional zoning with an emphasis made on the following:

- modern socioeconomic conditions;

- integration of functional zoning; and

- return to historically justified fuzzy functional zoning.

Most of the rural settlements need to be rebuilt on the territory of Northern Kazakhstan at the present stage. In this case, it is important to include the settlement in the planning structure of systems of various ranks. In general, the architectural and planning organization of a small settlement should be carried out through the formation of the developed structural and planning elements that have intersettlement significance.

The spatial structure of the theoretical model of a rural settlement includes the following components:

1. historical background;

2. trends in the formation of rural settlements;

3. main factors of the settlement formation;

4. historical stages and dominant factors;

5. trend to constant deterioration;

6. critical point; and

7. new approach, new vision as a synthesis of all factors and trends.

1. Historical background. The principle of "canon and pattern" had been taken as the basis for organizing the architectural space until the beginning of the 20th century (up to the 1917 revolution). The natural organic approach prevailed in the space organization. Historical continuity and folk traditions were the basis for the design.

With the restoration of the Soviet power, all the existing canons (historical, folk, and natural) were discarded, and other principles of organizing public life based on pseudoequality and pseudocollectivism were put forward, where everyone was an average standard element of a large mechanism. This influenced all areas of development of the society, including the organization of the architectural space.

2. The main trends in the rural settlement formation were the following: an increase in the number of settlements due to the development of new territories; the new social doctrine led to changes in the way of life of villagers, which was associated with the processes of collectivization and the emergence of forms of ownership (state farms, collective farms, state breeding farms, etc.); and the specialization and production focus of farms changed.

3. The main factors in the settlement formation were the following: natural climatic, cultural historical, socioeconomic, scientific, and technical. These factors are described as complex and multidimensional, including a variety of elements.

4. Historical stages and dominant factors. Five main periods can be distinguished in the historical stages of the village formation, the analysis of which leads to the conclusion that each stage has its own dominant factor and approach. For example, a natural historical approach was characteristic during the formation of the first permanent settlements on the territory of the region (stage 1); the dominant factor was natural. The second stage in the formation of permanent settlements was described by a traditional historical approach; the dominant factor was colonial. A national ethnographic approach to the settlement formation was characteristic at the third stage (from the mid-90s of the 19th century to the early 20th century); the dominant factor was geopolitical. The fourth stage was at the 50s of the 20th century. This stage was described by a standardized typical approach to the formation of rural settlements with a dominant political factor. The fifth stage of the village formation had a pseudoscientific approach with a dominant economic factor. The sixth stage was at the 80s of the 20th century and was described as a voluntarist typical approach.

5. Trend to constant deterioration. The pseudoscientific approach to the space formation led to the fact that only one factor from the whole complex of factors dominated at each subsequent historical stage. The rest were not taken into account. This led to a simplification and, accordingly, to a deterioration in the organization of living space at all levels each time. 
6. The critical point in time coincided with the period of the political and economic crisis (the perestroika period, 1985 - 1991). This period is described by the maximum destruction and decline in all areas (economic, industrial, social, etc.), which led to the general degradation of rural settlements.

7. The new approach is described by a synthesis of all factors and trends, in which the individual approach prevails in the organization of each specific settlement with the possibility of its change and development in accordance with the requirements of the changing time. The proposed model is not static but dynamic. In theory, the proposed model secures self-organization, self-development, and dynamic balance of the entire structure, which is the most optimal approach in ensuring the life processes.

The theoretical model is based on the following principles of organizing a rural settlement of a new type:

1. Environmental feasibility;

2. Flexibility in approach and space organization;

3. Opportunity for development and changes;

4. Taking into account a complex of individual specifics (regional, historical, natural, socioeconomic, construction and technical, etc.);

5. Each structural element of the village must be organized in accordance with the laws of aesthetics; and

6. Identification of key moments forming the space structure.

The key points may include the following:

- production evolvement due to the development of new agricultural technologies that influence its structure and organization;

- development of the residential area will be determined by harmony with nature and the standard of living at each specific historical (time) period;

- transport and communication frame should be multifunctional with minimum length and ensure safety; and

- buffer zone (zone of transition from external to internal) protects the internal structure of settlements from external harmful influences of any level: economic, natural, climatic, noise, dust, etc.

The interposition of all structural units of a rural settlement is determined by the optimal feasibility, including such concepts as economic feasibility, social feasibility, environmental, natural climatic, national ethnographic, and global standards.

\section{Conclusion}

1. The patterns of the village formation revealed in the work allow to conclude that a social urban planning scenario that takes into account all the individual specifics of the projected object needs to be created.

The social aspect of the proposed scenario lies in the need to take national, demographic, historical, everyday, and cultural requirements into account when designing each specific object.

The urban development aspect of the scenario includes the need to take natural, climatic, environmental, and historical factors into account when designing an object.

The theoretical model of the agricultural settlement formation is based on the set of requirements that take as many factors, trends, principles and design methods in a specific region as possible into account.

The theoretical model of the rural settlement formation proposed in the article has been developed based on the comprehensive analysis of rural areas of Northern Kazakhstan and sociological research and allows using the methods of architectural and urban development analysis to use the identified patterns to achieve programmable results.

2. It has been established in the course of the study that the new socioeconomic conditions of the independent state of the Republic of Kazakhstan, as well as internal and external relations, national, historical, natural climatic, and environmental specifics dictate the need to create a fundamentally new socioeconomic model of a rural settlement, which will require large capital investments, political, economic, and organizational efforts, and long terms.

3. Continuation of research in this direction will reveal the main practical tasks for the revival and development of agriculture and rural areas in the Republic of Kazakhstan.

Social studies, economic estimations, and architectural and planning solutions will be a new drive to the development of the following sciences: economics of private subsidiary farming, land management, planning and development of settlements, and village architecture.

The scientific significance of the work is as follows:

- on a national scale: there have been no studies of this issue or project proposals, and their implementation in the village development practice will yield a significant economic and social effect;

- on an international scale: this work will be interesting for the countries with private subsidiary farming and villages with economic centers; and

- impact of the obtained results on the development of science and the expected social and economic effect.

\section{REFERENCES}

[1] Ch. E. Le Corbusier. Tri formy rasseleniya [Three forms of 
settlement], Stroyizdat, Moscow, 1976.

[2] T. K. Basenov. Gradostroitelstvo Kazakhstana [Urban development of Kazakhstan], Kazakhstan, Almaty, 1973.

[3] O. K. Gurulev. Traditsii i sovremennost v arkhitekture sela [Traditions and modernity in village architecture], Stroyizdat, Moscow, 1982.

[4] A. V. Ikonnikov. Osnovy gradostroitelstva I planirovka selskikh naselennykh mest [Fundamentals of urban development and planning of rural settlements], Higher school, Moscow, 1982.

[5] V. N. Belousov. Osnovnyye problem rasseleniya [Main problems of settlement], Architecture of the USSR, Vol. 3, 3-12, 1974.

[6] A. E. Likhacheva. Arkhitekturno-planirovochnaya organizatsiya krestyanskikh fermerskikh khozyaystv $\mathrm{v}$ Zapadnoy Sibiri [Architectural planning organization of farms in Western Siberia]. PhD thesis: 18.00.02, The Novosibirsk State Academy of Architecture and Arts, Novosibirsk, 2007.

[7] Z. N. Yargina (ed.). Osnovy teorii gradostroitelstva [Fundamentals of the theory of urban development], Stroyizdat, Moscow, 1986.

[8] A. Zh. Abilov. Gradostroitelstvo I ustoychivoye razvitiye poseleniy v Kazakhstane: monografiya [Urban planning and sustainable development of settlements in Kazakhstan]: monograph, Publishing house Kaz GASA, Almaty, 2002.

[9] C. Chirianni. City as Open Work, Civil Engineering and Architecture, Vol. 5, No. 2, 66-70, 2017. DOI: 10.13189/cea.2017.050204

[10] A. Baburov, A. Gutnov, G. Dyumenton, et al. Novyy element rasseleniya [New element of settlement], Stroyizdat, Moscow, 18-21, 24, 1966.

[11] A. N. Beregovskikh. Ot gradostroitelstva k gradoustroystvu
[From urban development to urban planning]: monograph, Omskblankizdat, Omsk, 2018.

[12] G. I. Pustovetov. Arkhitektura selskikh poseleniy v novykh sotsialno-ekonomicheskikh usloviyakh: Zhilyye I proizvodstvennyye zdaniya I sooruzheniya [Architecture of rural settlements in new socioeconomic conditions: Residential and industrial buildings and structures]. Dissertation for the degree of Doctor of Architecture, Moscow architectural institute, Moscow, 2003.

[13] V. V. Musatov, Kh. A. Butusov, V. A. Novikov. Arkhitekturnoye proyektirovaniye agroindustrianykh kompleksov [Architectural design of agro-industrial complexes]: Textbook, Agropromizdat, Moscow, 1990.

[14] S. B. Pomorov. Vtoroye zhilishche gorozhan, ili dom na prirode [The second dwelling of the townspeople, or a house in the countryside]: monograph, NGAHA, Novosibirsk, 2004.

[15] A. A. Kornilova, Y. M. Khorovetskaya, S. E. Mamedov, T. Z. Ospanov, D. Y. Sarsembayeva. Territory Management: Urban Planning and Recreational Planning of Populated Areas in the Republic of Kazakhstan in the Second Half of the 20th Century, Journal of Environmental Management and Tourism, Vol. 10, No, 6, 1295-1302, 2019.

[16] A. A. Kornilova, S. E. Mamedov, Y. M. Khorovetskaya, G. A. Karabayev, T. A. Kiseleva. Historical aspects of the formation of rural settlements in northern Kazakhstan during the prerevolutionary period, Terra Sebus, Acta MuseiSubesiensis, Vol. 10, 271-285, 2018.

[17] M. Muya, C. Kaluba, I. N. Banda, S. Rattray, C. Mubemba, G. Mukelabai. Infrastructure Watch Culture: Zambia's Infrastructure Report Card, Civil Engineering and Architecture, Vol. 5, No. 1, 8-17, 2017. DOI: 10.13189/cea.2017.050102

[18] M. Sarafin. Countryside architecture - Renovation of the village, Architekura a Urbanizmus, Vol. 41, No, 1-2, 65-77, 2007. 